Cell Research (1998), 8, 231-240

\title{
Effects of laminin glycopeptides on metastasis-related behaviors of cancer cells
}

\author{
JIANG XIN NONG*, Rou LI ZHOU**, SHA ZHANG \\ Department of Cell Biology, Beijing Medical University, \\ Beijing 100083, China
}

\begin{abstract}
Our previous reports have shown that lamininglycopeptides (LN-GPs), the total glycopeptides prepared from laminin ( $\mathrm{LN}$ ), can prevent the experimental lung metastasis and liver metastasis of mouse cancer cells. In order to explore the anti-metastatic mechanism of LNGPs, we studied the effects of LN-GPs on metastasisrelated behaviors of cancer cells in vitro. LN-GPs did not affect cell survival. However, LN-GPs inhibited cell attachment and spreading of S180 cells on LN- and Matrigelsubstrate in dose-dependent and time-dependent manners. Moreover, inhibition of cell attachment and spreading on Matrigel substrates were much greater on Matrigel substrate than on LN substrate. In the presence of LN-GPs, S180 cells on LN substrate changed from a flattened polygonal shape to a round one, the migration of S180 cells on LN substrate decreased, and the number of a highly invasive human pulmonary giant carcinoma PG cells invading Matrigel filter in a Boyden chamber was reduced. LN-GPs thus have multiple inhibitory effects on cancer metastasisrelated behaviors.
\end{abstract}

Key words: Laminin, laminin glycopeptides, matrigel, cancer cells, cancer metastasis.

\section{INTRODUCTION}

The metastasis of cancer cells is a very complicated process, involving multiple

* Department of Cell Biology, Wuhan University, Wuhan 430072, China

** Corresponding author, Fax: (010) 62358270, E-mail: rlzhou@mail.bjmu.edu.cn 
steps. During this process, cancer cells interact with basement membranes (BM), invade and pass through them at least three times[1]. Laminin (LN), a major noncollagenous glycoprotein in the BM, plays important roles in cancer metastasis[1, 2]. In vitro, LN enhances the attachment, spreading[1], migration[3] of many kinds of cancer cells. LN also induces cancer cells to secret type IV collagenase and disrupts BM structures[4].

The biological function of $\mathrm{LN}$ is mediated by $\mathrm{LN}$ receptors on the cell surface. A number of these receptors have the characteristics of carbohydrate binding proteins[5], indicating the possible role of carbohydrate moieties of LN. It has been reported that LN carbohydrates participated in the cell attachment[6] and cell spreading[7] of cancer cells. Furthermore, we have found that certain sugars, including $\mathrm{N}$-acetyl-neuranminic acid, a -methyl-D-mannose, lactose and $\mathrm{N}$-acetyl-lactosamine, but not glucose, galactose and mannose, inhibited the binding of a various cancer cells to LN[8]. Therefore, it seems that carbohydrate chains may be involved in the recognition between cancer cells and the MB. On the basis of these studies, the glycopeptides were isolated from $\mathrm{LN}$ and biological experiments demonstrated that LN-GPs were powerful inhibitors for blocking the interactions between cancer cells and LN, and also for blocking the interaction between the isolated $67 \mathrm{kDa} \mathrm{LN}$ receptor and LN[9]. Later, we further documented the ability of LN-GPs to prevent the cancer metastasis in an in vivo system, the experimental lung and liver metastasis of mouse melanoma cells $[10,11]$.

In this paper, the in vitro effects of LN-GPs on metastasis-related behaviors of cancer cells, including cell attachment, spreading, migration, and invasiveness will be reported.

\section{MATERIALS AND METHODS}

\section{Materials}

Cycloheximide (CH), HEPES, MTT, PI, Agarose and BSA were purchased from Sigma; RPMI1640 was purchased from JR Scientific (USA); LN was prepared in our laboratory from mouse Engelbreth-Holm-Swarm (EHS) tumor as described by Timple[12]; Matrigel was prepared in our laboratory from EHS tumor as described by Kleinman[13]; LN-GPS was prepared in our laboratory from LN[6]. NIH3T3 chemotatic factor was prepared as described by Albini[14].

Mouse sarcoma cell line S180 was obtained from the Department of Cell Biology, Beijing Normal University; Human gastric carcinoma cell line BGC-823 was obtained from the Department of Pharmacology, Beijing Medical University (BMU); Human pulmonary giant carcinoma cell line PG was obtained from the Department of Pathology, BMU. All cell lines were cultured in RPMI-1640 supplemented with $10 \%$ fetal calf serum, penicillin (100 unit/ml), streptomycin $(100 \mu \mathrm{g} / \mathrm{ml})$ and $2 \%$ HEPES.

Scanning Electronic Microscopy S-450 is from Hitachi (Jap); Flow Cytometer FACS-440 is from B.D. Co (USA) and $8 \mathrm{~mm}$ pore size Nucleopore Polycarbonate Filters without PVP from Poretics Co. (USA) were used in this work; Boyden Chamber was made in China according to the model purchased from USA. 


\section{MTT assay}

$4 \mu \mathrm{g}$ LN was coated onto the bottom of 96-well plastic plates as previously reported by Zhou et al[1]. Control wells contained no LN. 1\% BSA in PBS was then added (overnight at $4{ }^{\circ} \mathrm{C}$ ) to block the unsaturated plastic surface. S180 cells were washed 3 times with PBS and incubated with serum free $\mathrm{CH}(25 \mu \mathrm{g} / \mathrm{ml})-\mathrm{RPMI}-1640$ at $37{ }^{\circ} \mathrm{C}$ in $5 \% \mathrm{CO} 2$ for $4 \mathrm{~h}$ to prevent the production of endogenous proteins. Then, S180 cells were harvested and resuspended in serum free CH-RPMI1640 at a concentration of $4 \times 10^{5}$ cell $\mathrm{s} / \mathrm{ml}$. Cell viability detected by Trypan Blue exclusion was found to be $>98 \% .100 \mu \mathrm{l}$ cell suspension in the presence or absence of LN-GPs $(50 \mu \mathrm{g} / \mathrm{ml})$ was added to wells and incubated at $37{ }^{\circ} \mathrm{C}$ in $5 \% \mathrm{CO}_{2}$ for $18 \mathrm{~h}$. MTT assay[15] was performed as following: $20 \mu \mathrm{l} \mathrm{MTT} \mathrm{(} 5 \mathrm{mg} / \mathrm{ml}$ ) was added to each well and incubated with cells at $37{ }^{\circ} \mathrm{C}$ for $2 \mathrm{~h}$. $50 \mu \mathrm{l}$ SDS (10\%) was then added to each well and incubated further at $37{ }^{\circ} \mathrm{C}$ for $6 \mathrm{~h}$. The value of OD 570 was measuned by ELISA reader, quadruplicates were measured in each sample.

\section{Trypan blue exclusion assay}

BGC-823 cells were treated as S180 cells in MTT assay and resuspended in serum free $\mathrm{CH}$ RPMI-1640 at $5 \times 10^{5}$ cells $/ \mathrm{ml}$. Cells in the presence or absence of LN $(20 \mu \mathrm{g} / \mathrm{ml})$ and LN (20 $\mu \mathrm{g} / \mathrm{ml})$ plus LN-GPs $(100 \mu \mathrm{g} / \mathrm{ml})$ were incubated at $37{ }^{\circ} \mathrm{C}$ in $5 \% \mathrm{CO}_{2}$ for $24 \mathrm{~h}$. Cell viability was detected either before or after incubation on the basis of trypan blue exclusion.

\section{Cell attachment assay}

$20 \mu \mathrm{g} \mathrm{LN}$ in PBS or $50 \mu \mathrm{g}$ Matrigel in PBS was added into glass vials with flat bottom (Ф2.2 $\mathrm{cm})$ to prepare LN or Matrigel substrate coating[1]. Uncoated bottom of glass vials was used as control. 1\% BSA in PBS was added to each glass vials (overnight at $4{ }^{\circ} \mathrm{C}$ ). The cell suspension of S180 cells $\left(2 \times 10^{6}\right.$ cells $\left./ \mathrm{ml}\right)$ was prepared as in MTT assay and the cell viability was $>98 \%$. Cells $\left(2 \times 10^{5}\right)$ in the presence of various doses of LN-GPs $(0,12.5,25,37.5 \mu \mathrm{g})$ were added into glass vials in a final volume of $0.5 \mathrm{ml}$ and incubated at $37{ }^{\circ} \mathrm{C}$ in $5 \% \mathrm{CO}_{2}$ for $6 \mathrm{~h}$. Unattached cells were discarded, the number of attached cells was determined by detecting the activity of LDH[1]. All experiments were performed in triplicates.

\section{Cell spreading assay}

This experiment was performed similarly to cell attachment assay. The difference was that S180 cells were incubated at $37{ }^{\circ} \mathrm{C}$ in $5 \% \mathrm{CO}_{2}$ for 2,4 , or $6 \mathrm{~h}$. The percentage of spreading cells was calculated under phase contrast inverted microscope.

\section{Cell surface morphology}

The surface of glass coverslip ( $11 \times 11 \mathrm{~mm}$ ) was coated with $10 \mu \mathrm{g}$ LN and put into glass vials with LN-coated surface upward. Uncoated coverslips were used as control. 1\% BSA in PBS was added to each glass vials (overnight at $\left.4{ }^{\circ} \mathrm{C}\right)$. Cell suspension of $\mathrm{S} 180$ cells $\left(5 \times 10^{6}\right.$ cells $/ \mathrm{ml}$ ) was prepared with viability $>98 \% .5 \times 10^{5}$ cells in the presence or absence of LN-GPs $(37.5 \mu \mathrm{g})$ were added to each glass vials in a final volume of $0.5 \mathrm{ml}$ and incubated at $37{ }^{\circ} \mathrm{C}$ in $5 \% \mathrm{CO}_{2}$ for $6 \mathrm{~h}$. Unattached cells were discarded, attached cells were treated as the method used to prepare SEM samples. Then, the cell surface was observed under SEM (S-450). Triplicates were prepared for each sample.

\section{Cell migration assay}

The method used here was referred to agarose drop method described by Varani et al[16]. S180 cells were washed 3 times with PBS and suspended in serum free RPMI-1640. The cell viability was $>96 \%$. The cell pellet $\left(10^{8}\right.$ cells $\left./ \mathrm{ml}\right)$ was added to serum free RPMI-1640 containing $0.5 \%$ (W/V) agarose at the ratio of 1:3 (V/V). $1 \sim 2 \mu \mathrm{l}$ droplets of such cell suspension contained either LN $(20 \mu \mathrm{g} / \mathrm{ml}), \mathrm{LN}(20 \mu \mathrm{g} / \mathrm{ml})$ plus LN-GPs $(100 \mu \mathrm{g} / \mathrm{ml})$, Matrigel $(50 \mu \mathrm{g} / \mathrm{ml})$, or Matrigel (50 
$\mu \mathrm{g} / \mathrm{ml})$ plus LN-GPs $(100 \mu \mathrm{g} / \mathrm{ml})$ were delivered into the wells of 24 -well plates. In control group, the cell droplets contained no supplemented material(s) as just described. The 24 -well plates were then placed at $4^{\circ} \mathrm{C}$ for $10 \mathrm{~min}$. The overlay medium with the same serum free RPMI-1640 medium as the agarose droplets was added into each well. Each sample was performed in quadruplets. The 24-well plates were incubated at $37{ }^{\circ} \mathrm{C}$ in $5 \% \mathrm{CO}_{2}$ for $18 \mathrm{~h}$. The distance between the drop edge and the front of migrating cells was measured by phase contrast inverted microscopy via calibrated grid mounted with in the eyepiece.

\section{Invasion assay}

This experiment was performed as described by Albini et al[14]. The highly metastatic PG cells were washed 3 times with PBS and resuspended in serum free RPMI-1640 at $5 \times 10^{5} \mathrm{cells} / \mathrm{ml}$. The cell viability was $>96 \%$. Cell suspensions in the presence or absence of LN-GPs $(100 \mu \mathrm{g} / \mathrm{ml})$ were preincubated at $37{ }^{\circ} \mathrm{C}$ in $5 \% \mathrm{CO}_{2}$ for $1 \mathrm{~h}$ before use. $200 \mu$ l NIH3T3 chemotatic factor was added into blind wells of Boyden chamber. Filters $(\Phi 13 \mathrm{~mm})$ were overlayed onto the blind wells, the chambers were assembled. Matrigel $(120 \mu \mathrm{g})$ was added onto filters at $0{ }^{\circ} \mathrm{C}$ and then placed at 37 ${ }^{\circ} \mathrm{C}$ for 30 min. Cells $\left(2 \times 10^{5}\right)$ were then put into top wells of Boyden chamber and incubated at $37{ }^{\circ} \mathrm{C}$ in $5 \% \mathrm{CO}_{2}$ for $6 \mathrm{~h}$. Then filters were removed from chambers and stained with hematoxylin. Each sample were in quadruplicates. The number of cells that invaded into the filter was counted under microscope for five high-power fields (hpf).

\section{RESULTS}

\section{Effects of LN-GPs on cancer cell survival}

The results of MTT Assay (Tab 1) showed that there were no obvious difference between S180 cells incubated for $18 \mathrm{~h}$ in the presence or absence of LN-GPs (50 $\mu \mathrm{g} / \mathrm{ml}$ ), suggesting that LN-GPs had no toxic effect on cancer cell survival. The trypan blue exclusion assay also demostrated that there was no difference in cell viability either before or after incubation of BGC-823 cancer cells with LN-GPs $(100 \mu \mathrm{g} / \mathrm{ml})$ for $24 \mathrm{~h}$ (data not shown). Thus, it seems that LN-GPs used have no cytotoxic effect on either S180 sarcoma or BGC-823 carcinoma cells.

Tab 1. The $\mathrm{OD}_{570}$ values of $\mathrm{S} 180$ cells incubated in the presence or absence of LN-GPs $(50 \mu \mathrm{g} / \mathrm{ml})$ at $37{ }^{\circ} \mathrm{C}$ in $5 \% \mathrm{CO}_{2}$

\begin{tabular}{ccccc}
\hline Group & LN coatng $(\mu \mathrm{g})$ & LN-GPS $(\mu \mathrm{g} / \mathrm{ml})$ & OD $_{570}$ & $\mathrm{P}^{*}$ \\
\hline control & 0 & 0 & $1.78 \pm 0.004$ & $* *$ \\
1 & 4 & 0 & $1.69 \pm 0.005$ & $>0.1$ \\
2 & - & 50 & $1.71 \pm 0.003$ & $>0.1$ \\
3 & 0 & 50 & $1.79 \pm 0.006$ & $>0.1$ \\
\hline
\end{tabular}

*: compared to control group, $\mathrm{n}=12 ; * *: \mathrm{X} \pm \mathrm{SD}$.

for $18 \mathrm{~h}$.

\section{Effects of LN-GPS on metastasis-related behaviors of cancer cells}

The results of cell attachment assay as shown in Fig 1 indicated that in the presence of LN-GPs for $6 \mathrm{~h}$, the attachment of S180 cells on LN or Matrigel substrate was inhibited in a dose-dependent manner, however cell attachment on Matrigel substrate was inhibited much more strongly. 
Jiang $\mathrm{XN}$ et al

Fig 1. Does-dependent effects of LN-GPs on cell attachment of S180 cells on LN and Matrigel substrate. The cells were incubated in the presence of various concentration of LN-GPs $(0,25,50,75 \mu \mathrm{g} / \mathrm{ml})$ at $37^{\circ} \mathrm{C}$ in $5 \% \mathrm{CO}_{2}$ for $6 \mathrm{~h}$.
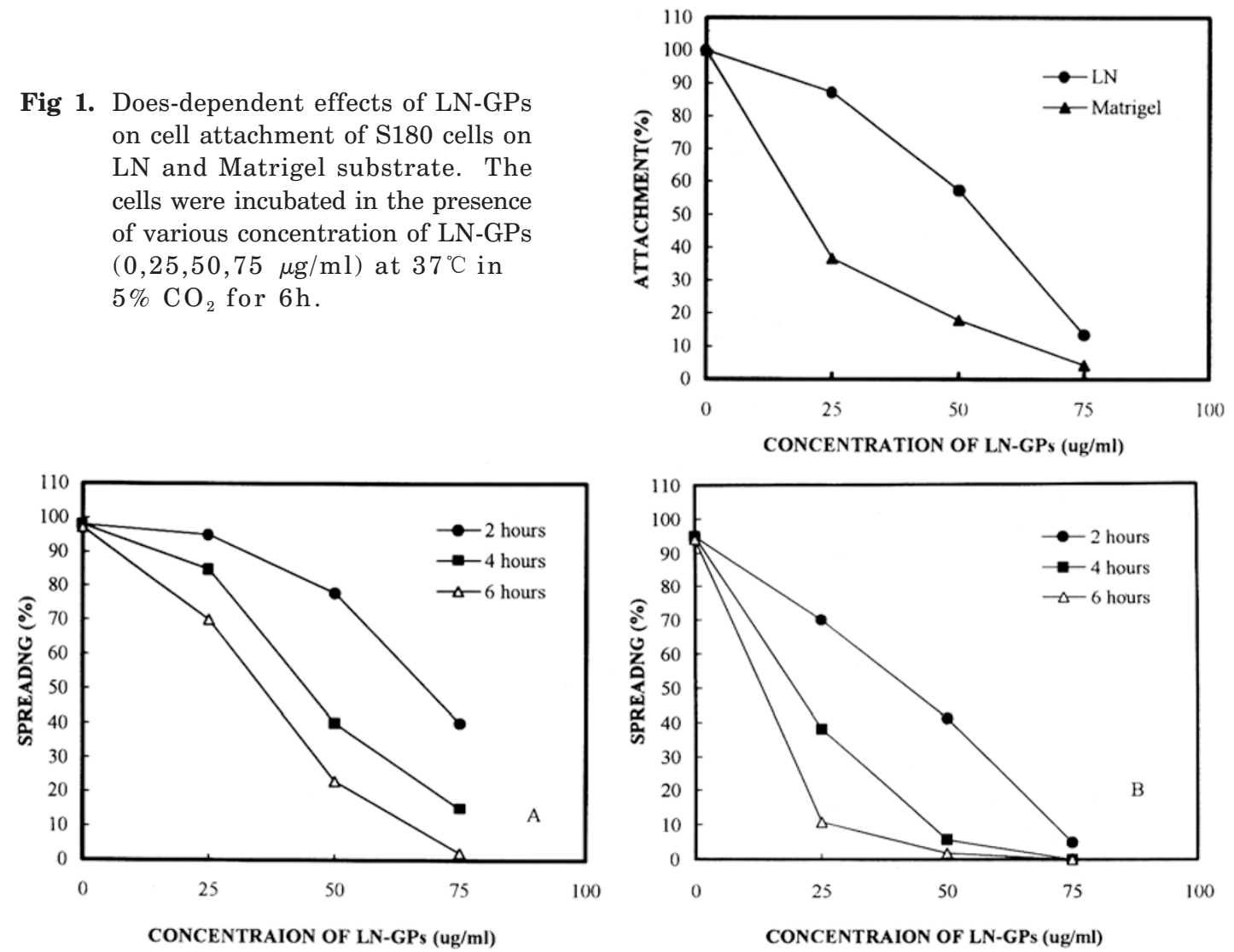

Fig 2. Does-dependent effects of LN- GPs on cell spreading of S180 cells on LN (A) and Matrigel (B) substrates. The cells were incubated in the presence of various concentration of LN$\operatorname{GPs}(0,25,50,75 \mu \mathrm{g} / \mathrm{ml})$ at $37^{\circ} \mathrm{C}$ in $5 \% \mathrm{CO}_{2}$ for 2,4 and $6 \mathrm{~h}$.
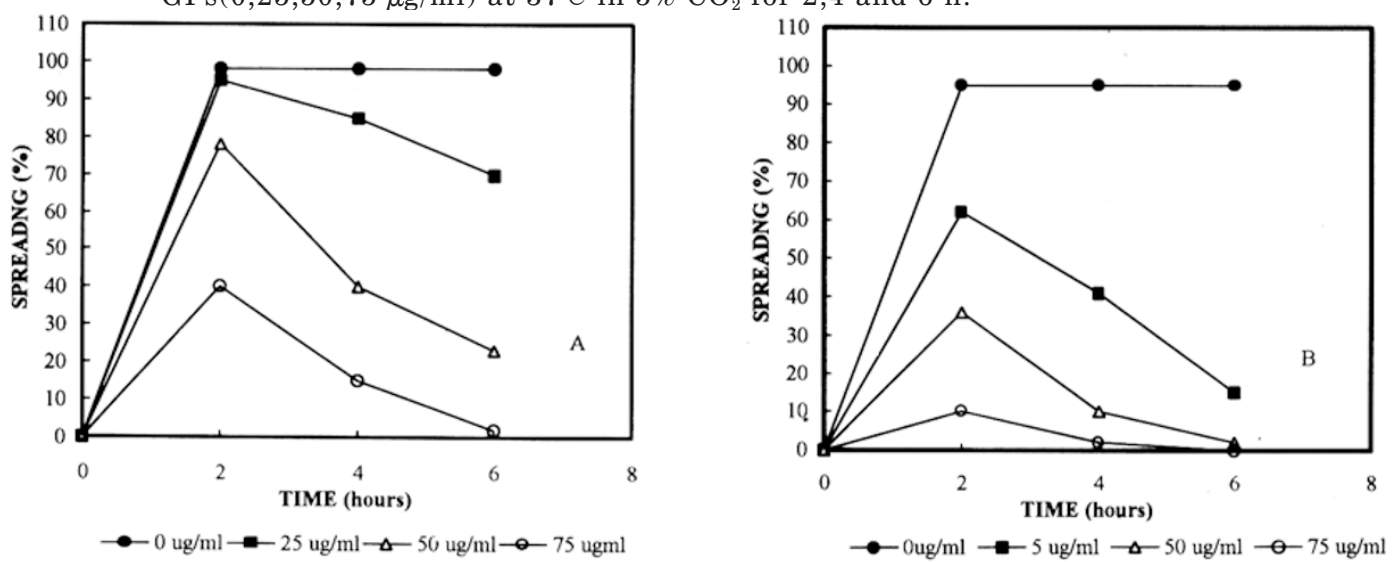

Fig 3. Time-dependent effects of LN-GPs on cell spreading of S180 cells on LN (A) and Matrigel (B) substrate. The cells were incubated in the presence of various concentration of LN-GPs $(-\bullet-0 \mu \mathrm{g},-\square-25 \mu \mathrm{g},-\triangle-50 \mu \mathrm{g},-\bigcirc-75 \mu \mathrm{g})$ at $37{ }^{\circ} \mathrm{C}$ in $5 \% \mathrm{CO}_{2}$ for 2,4 and $6 \mathrm{~h}$. 
Laminin glycopetides and metastatic behaviors of cancer cells
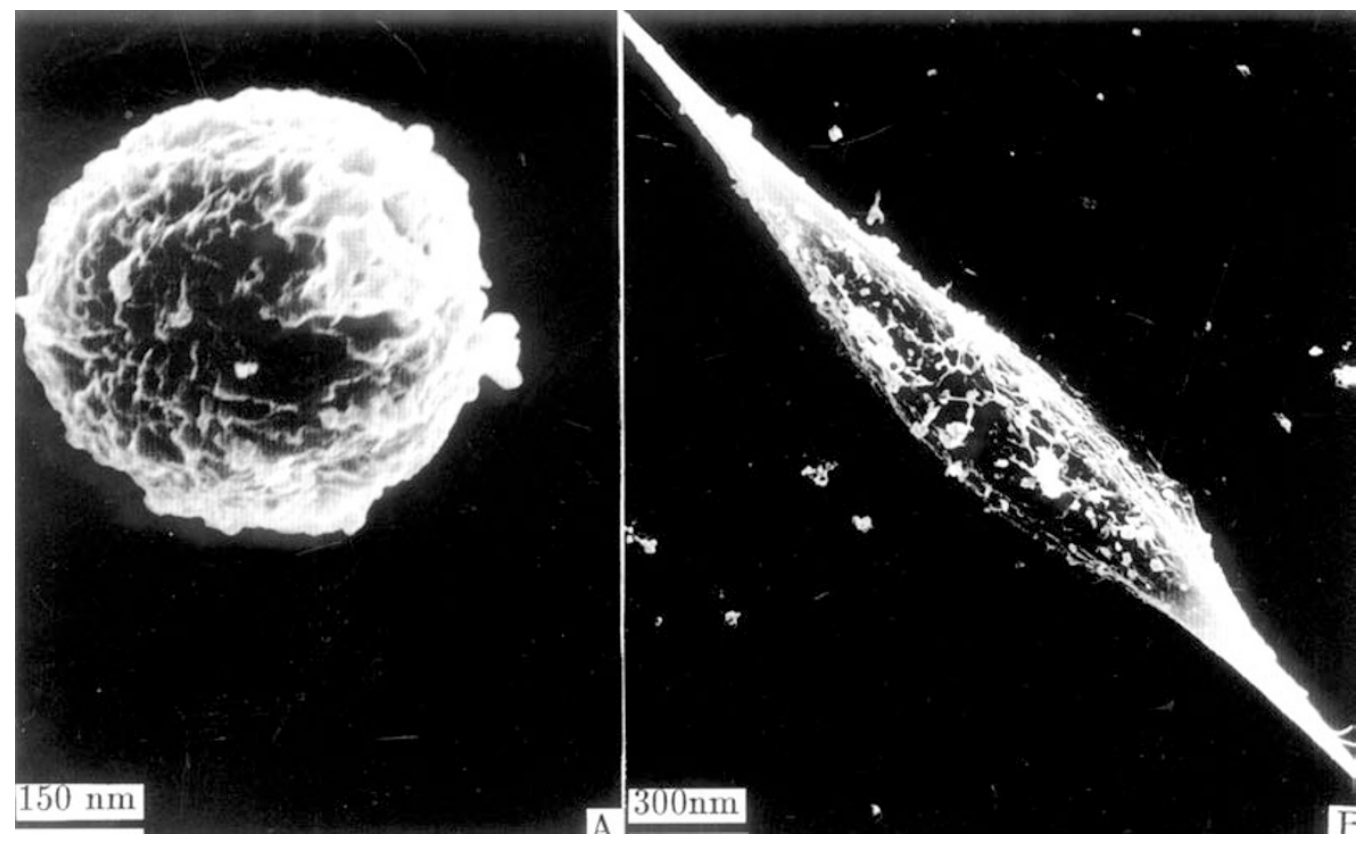

Fig 4. Cell surface morphology of S180 cells observed under SEM. the cells were incubated at $37{ }^{\circ} \mathrm{C}$ in $5 \% \mathrm{CO}_{2}$ for $6 \mathrm{~h}$. A: cells attached onto bare glass showed round shape with numerous ruffles (X6000); B: Cells attached onto LN substrate showed polygonal and flattened shape with long pseudopodia and fewer ruffles (X3000); C: Cells attached onto LN substrate in the presence of LN-GPs $(75 \mu \mathrm{g} / \mathrm{ml})$ showed polygonal or round shape with shorter pseudopodia and numerous ruffles (X4000).

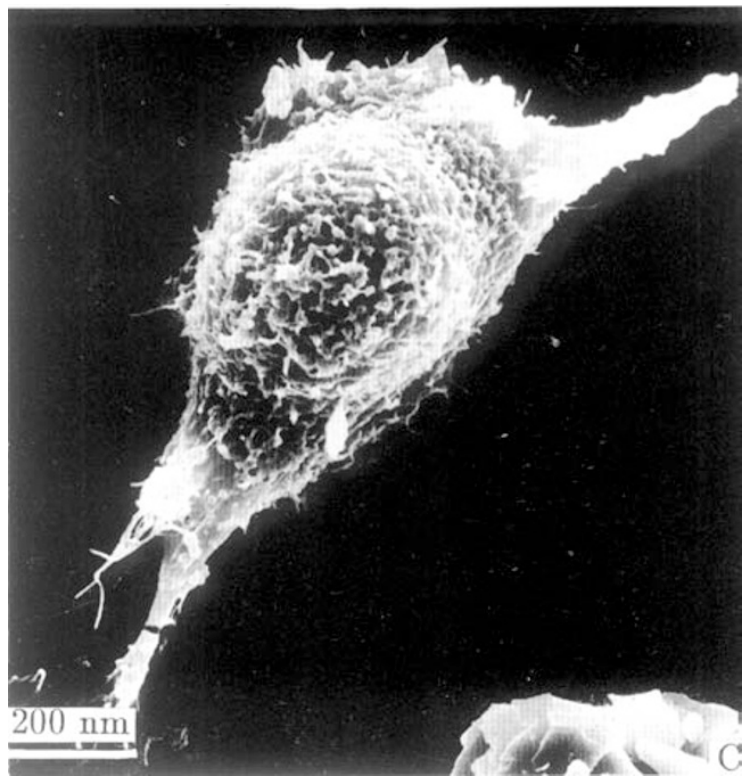


From the cell spreading assay we found that after the treatment of S180 cells with various concentrations of LN-GPs for a definite period of time, a dose-dependent and a time-dependent inhibition of cell spreading on $\mathrm{LN}$ substrate (Figs 2, $3 \mathrm{~A}$ ) or Matrigel substrate (Figs 2, 3 B) were observed. Similar to cell attachment, cell spreading on Matrigel substrate was also much more greatly inhibited.

From the observation of cell surface under SEM, it was noticeable that the S180 cells attached onto bare glass showed round shape with numerous ruffles (Fig $4 \mathrm{~A}$ ); while the cells attached onto LN substrate displayed polygonal and flattened shape with long pseudopodia and fewer ruffles (Fig 4 B). After the treatment with LNGPs $(50 \mu \mathrm{g} / \mathrm{ml})$ for $6 \mathrm{~h}$, cells attached onto LN substrate showed polygonal or round shape with shorter pseudopodia and numerous ruffles, just similar to the cell surface morphology of some cells attached onto bare glass (Fig 4 C).

The results of cell migration assay demonstrated that in the control group, almost all cells maintained in the original position and only a few cells traversed the drop edge. LN $(20 \mu \mathrm{g} / \mathrm{ml})$ and Matrigiel $(50 \mu \mathrm{g} / \mathrm{ml})$ promoted the migration of S180 cells to the drop edge and increased greatly the number of migrating cells. However, LN-GPs $(100 \mu \mathrm{g} / \mathrm{ml})$ inhibited both the promoting effects of LN or Matrigel on cell migration (Fig 5).

In the presence of LN-GPs $(100 \mu \mathrm{g} / \mathrm{ml})$, the number of highly metastatic PG cells that invaded into filters with Matrigel on the surface was $18.8 \pm 3.96$ (X \pm $\mathrm{SD}) / \mathrm{hpf}$ (Fig $6 \mathrm{~A}$ ), in comparison with a value of $43.8 \pm 10.71(\mathrm{X} \pm \mathrm{SD}) / \mathrm{hpf}$, for the control without LN-GPs (Fig $6 \mathrm{~B}$ ), indicating the strong inhibition of PG cells invasion by LN-PGs.

Fig 5. Effects of LN, Matrigel and LNGPs on the migration of S180 cells. The cells were incubated in the presence of either LN $(20 \mu \mathrm{g} / \mathrm{ml})$, or LN + LN-GPs $(100 \mu \mathrm{g} / \mathrm{ml})$; Matrigel $(50 \mu \mathrm{g} / \mathrm{ml})$, or Matrigel + LN-GPs $(100 \mu \mathrm{g} / \mathrm{ml})$, as compared with that of the control without such materials at $37{ }^{\circ} \mathrm{C}$ in $5 \% \mathrm{CO}_{2}$ for $18 \mathrm{~h}$.

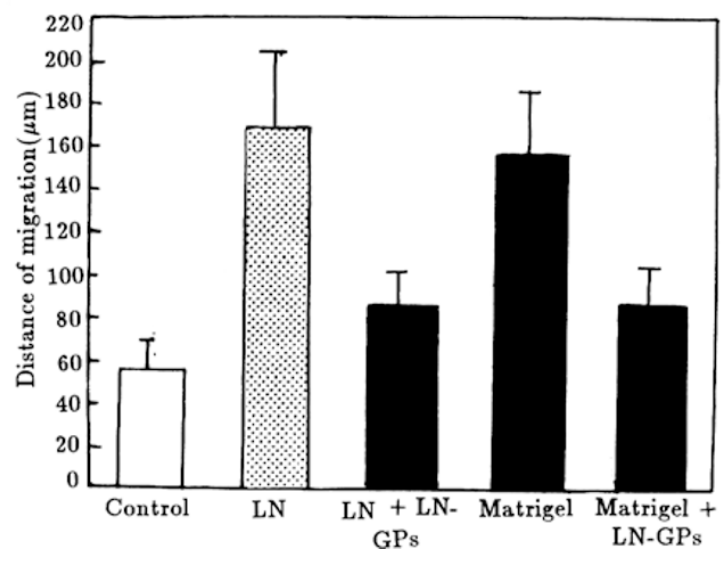


Laminin glycopetides and metastatic behaviors of cancer cells

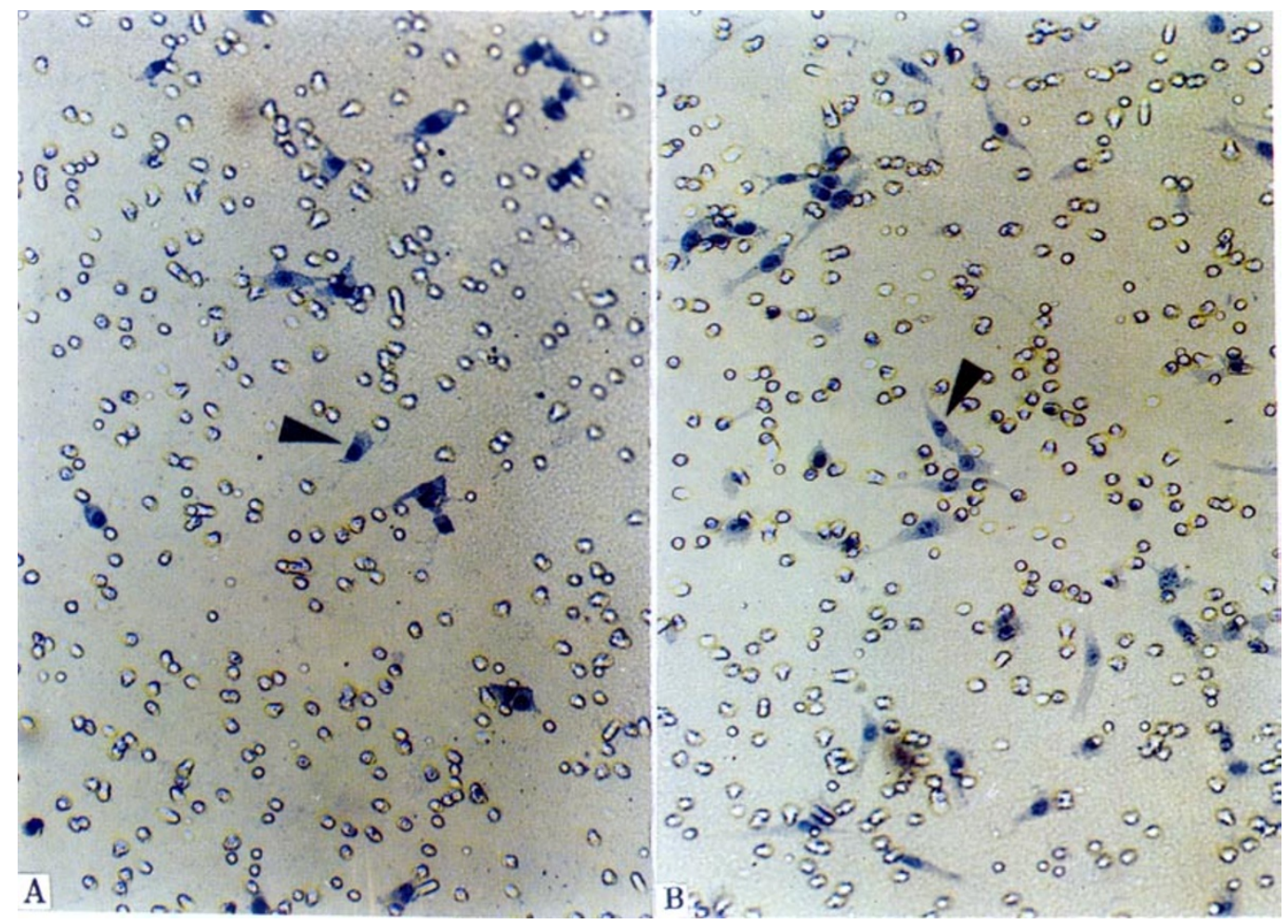

Fig 6. The detection of invasion of PG cells. The cells were incubated at $37{ }^{\circ} \mathrm{C}$ in $5 \%$ $\mathrm{CO}_{2}$ for $6 \mathrm{~h}$. A: in the presence of LN-GPs $(100 \mu \mathrm{g} / \mathrm{ml})$; B: in the absence of LN-GPs. The invaded cells were marked by arrows.

\section{DISCUSSION}

It has been reported that the carbohydrate moieties of $\mathrm{LN}$ are involved in the cell attachment[6] and spreading[7] of different cancer cells. Matrigel is an artificial $\mathrm{BM}$ preparation extracted from mouse EHS tumor. The major component of Matrigel is LN, the others are collagen IV, heparin sulfate proteoglycans, and entactin /nidogen[13]. Because Matrigel is more like BM than LN, it is also used as substrate for cell attachment and spreading assays. It is evident from the present work, both Matrigel and LN can promote cell attachment, spreading and migration; LN-GPs can inhibit the promoting effects of LN and Matrigel. The inhibitory effects on S180 cells plated onto Matrigel substrate were found to be much more strongly than those onto LN substrate. The reason is not well understood.

Both the promotion of cell spreading by LN and its inhibition by LN-GPs are time-dependent. The explanation for this phenomenon is very complicated. It may involve not only the assembly and disassembly of cell cytoskeleton, but also signal transduction and gene expression. Recently, LN has been considered as a signal molecule[17]. The binding of the LN receptors to LN may trigger signal transduction, 
and it is possible that LN-GPs may bind competitively to LN receptors. Integrin mediated FAK-MAPK pathway is very important in signal transduction triggered by binding of extracellular matrix components to integrins[17]. Recently, we have found that the focal adhesion formation and FAK expression in focal adhesion can be promoted by LN and inhibited by LN-GPs, and the expression of a number of genes can be specifically induced by putting cancer cells onto LN, and the LN-GPs can inhibit some of such induced gene expression (unpublished data). Therefore, cell spreading is a phenomenon coupled not only to cytoskeleton assembling, but also to many other intracellular biochemicel events, including gene expression.

Moreover, cancer cell spreading on LN or Matrigel substrate was inhibited much more easily than cancer cell attachment. Since the first identification of the $67 \mathrm{kDa}$ LN receptor, a large number of LN receptors have now been reported[18]. The interaction of cancer cells with LN would be mediated differentially by the bindings of different LN receptors to different parts of LN molecule and carbohydrate chains are involved in some of the binding. It is possible that different combination of receptors may be involved in cell attachment and cell spreading; also different components of LN-GPs may interrupt differentially to cell attachment and cell spreading. To test such posibility, the LN-GPs should be further fractionated, and the biological effects of various active components should be studied separately.

Likewise, the different cell surface appearances of cells on LN in the presence or absence of LN-GPs under SEM may indicate that LN-GPs can alter the assembly and disassembly of the cytoskeleton, thus affecting not only cell shape, but also cell spreading, migration and invasiveness.

The mechanism of inhibition of the cancer cell invasiveness induced by LN-GPs is also difficult to explain at the moment. It was reported that the attachment onto LN can induce malignant cancer cells to secrete type IV collagenase and disrupt the basement membrane[5]. Possibly, LN-GPs, via its interfering with the binding between LN and LN receptors, can decrease the ability of PG cells to secrete type IV collagenase, thereby decreasing their invasion ability.

Taken together, the results of in vitro studies on the effect of laminin glycopeptides on metastatic behaviors of different cancer cells suggest that LN-GPs can manifest multiple anti-metastatic roles. It is hoped that further sustained studies on the basic mechanism of the effect of LN-GPs, on cancer cells may contribute from a different angle to our understanding towards cancer cell invasion and metatasis in vivo.

\section{ACKNOWLEDGEMENT}

This work is supported by the National Nature Science Foundation of China, No. 39180024. 
Laminin glycopetides and metastatic behaviors of cancer cells

\section{REFERENCES}

[1] Zhou Rouli, Gao Suying, Wang Su, et al. Laminin stimulates the attachment,spread and ${ }^{3} \mathrm{H}-$ TdR incorporation of cancer cells. Chinese Biochemical J 1987; 3:261-9. (in Chinese)

[2] Castronovo V. Laminin receptors and laminin-binding proteins during tumor invasion and metastasis. Invasion and Metastasis 1993; 13:1-30.

[3] McCarthy JB, Rurcht LT. Laminin and fibronectin promote the haptotactic migration of B16 mouse melanoma cells in vitro. J Cell Biol 1983; 98:1474-80

[4] Emonard H, Christiame Y, Smet M. Type IV and interstitial collagenolytic activities in noemal and malignant trophoblast cells are specifically regulated by the extracellular matrix. Invasion and Metastasis 1990; 10:170-7.

[5] Tanzer ML, Dean III, JW, Chandrasekaran S. Cell signaling: A role for laminin carbohydrates. TIGG 1991; 13:302-14.

[6] Zhao Yong, Zhou Rouli, Lan Li. Effects of LN-glycopeptides on attachment of cancer cells to extracellular matrix. Chin Biochem J 1992; 8:288-91.

[7] Dean III, JW, Chandrasekaran S, Tanzer ML. A biological role of the carbohydrate moieties of laminin. J Biol Chem 1990; 265:12553-62.

[8] Zhang Qinyun, Zhou Rouli. The roles of saccharides in the recognition and binding of murine Lewis lung carcinoma cells with laminin. J Beijing Med Univ 1990; 22:434-6. (in Chinese)

[9] Zhang Qinyun, Zhou Rouli. Roles of saccharides in the binding of laminin receptor with its ligand. J Beijing Med Univ 1991; 23:106-8. (in Chinese)

[10] Zhao Yong, Zhou Rouli. The role of laminin-glycopeptides in experimental metastasis of mouse B16 melanoma cells. J Beijing Med Univ 1990; 24:404. (in Chinese)

[11] Liu Yiping, Zhou Rouli, Zhang Sha. Laminin-glycopeptides inhibit the experimental liver metastasis of mouse B16 melanoma cells. J Beijing Med Univ 1996; 28:91. (in Chinese)

[12] Timple R, Rohde H, Robey PG, Rennard SI, Foidart JM, Martin GR. Laminin- A glycoprotein from basement membranes. J Biol Chem 1979; 254:9933-7.

[13] Kleinman HK, McGarvey ML, Hassell JR, Star VL, Cannon, FB, Laurie GW, Martin GR. Basement membrane complexes with biological activity. Biochemistry 1986; 25:312-8.

[14] Albini A, Iwamoto Y, Kleinman HK, Martin GR, Aaronson SA, Kozlowski JM, McEwan RN. A rapid in vitro assay for quantitating the invasive potential of tumor cells. Cancer Res 1987; 47:3239-45.

[15] Chen Zhesheng, Sun Mingjie, Liu Zhenglong, Zhang Liping, Shen Haizhong. Study on activities of human lymphocytes and mouse macrophages using MTT assay. Shanghai J Immu 1992; 12:269-71. (in Chinese)

[16] Varani J, Orr W, Ward PA. A comparison of the migration pattern of normal and malignant cells in two assay systems. Am J Patho 1978; 90:159-71.

[17] Clorke EA, Brugge JS. Integrins and signal transduction pathways:The road taken. Science $1995 ; 268: 233-9$.

[18] Mecham RP. Laminin receptors. Annu Rev Cell Biol 1991; 7:71-91.

Received Nov-13-1997. Revised July-10-1998. Accepted July-26-1998. 